\title{
DISCLAIMER
}

This report was prepared as an account of work sponsored by an agency of the United States Government. Neither the United States Government nor any agency thereof, nor any of their mployees, makes any warranty, express or implied, or assumes any legal liability or responsiility for the accuracy, completeness, or usefulness of any information, apparatus, product, or rocess disclosed, or represents that its use would not infringe privately owned rights. Refernce herein to any specific commercial product, process, or service by trade name, trademark, nanufacturer, or otherwise does not necessarily constitute or imply its endorsement, recomnendation, or favoring by the United States Government or any agency thereof. The views nd opinions of authors expressed herein do not necessarily state or reflect those of the Inited States Government or any agency thereof.
EGG-2239

Distribution Categories: UC66-A, D, G

\section{PRICKETT AND LONNQUIST AQUIFER SIMULATION PROGRAM FOR THE APPLE II MINICOMPUTER}

$\mathrm{EGG}--2239$

DE83 008120

\author{
Laurence C. Hull
}

Published February 1983

\section{Geosciences Branch Earth and Life Sciences Office EG\&G Idaho, Inc.}

Prepared for the

U.S. Department of Energy Idaho Operations Office 


\section{DISCLAIMER}

This report was prepared as an account of work sponsored by an agency of the United States Government. Neither the United States Government nor any agency Thereof, nor any of their employees, makes any warranty, express or implied, or assumes any legal liability or responsibility for the accuracy, completeness, or usefulness of any information, apparatus, product, or process disclosed, or represents that its use would not infringe privately owned rights. Reference herein to any specific commercial product, process, or service by trade name, trademark, manufacturer, or otherwise does not necessarily constitute or imply its endorsement, recommendation, or favoring by the United States Government or any agency thereof. The views and opinions of authors expressed herein do not necessarily state or reflect those of the United States Government or any agency thereof. 


\section{DISCLAIMER}

Portions of this document may be illegible in electronic image products. Images are produced from the best available original document. 


\section{ABSTRACT}

The Prickett and Lonnquist two-dimensional groundwater model has been programmed for the Apple II minicomputer. Both leaky and nonleaky confined aquifers can be simulated. The model was adapted from the FORTRAN version of Prickett and Lonnquist. In the configuration presented here, the program requires $64 \mathrm{~K}$ bits of of memory. Because of the large number of arrays used in the program, and memory limitations of the Apple II, the maximum grid size that can be used is 20 rows by 20 columns. Input to the program is interactive, with prompting by the computer. Output consists of predicted head values at the row-column intersections (nodes). 


\section{CONTENTS}

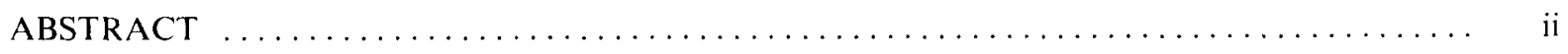

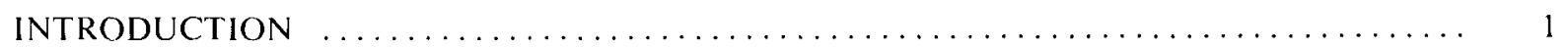

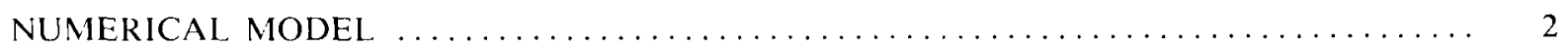

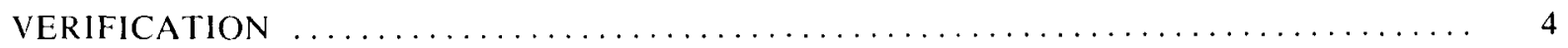

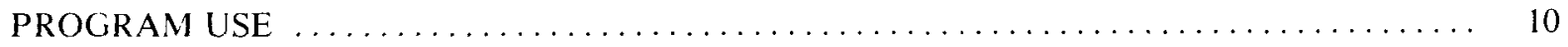

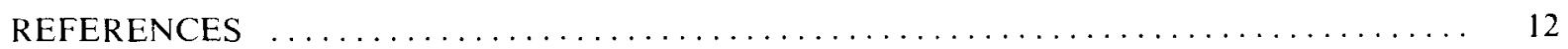

APPENDIX A-EXAMPLE PROGRAM OUTPUT $\ldots \ldots \ldots \ldots \ldots \ldots \ldots \ldots \ldots \ldots \ldots$

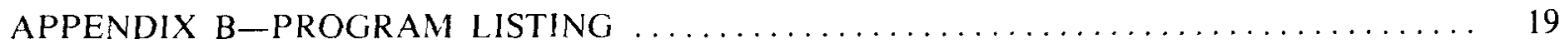




\section{PRICKETT AND LONNOUIST AQUIFER SIMULATION PROGRAM FOR THE APPLE II MINICOMPUTER}

\section{INTRODUCTION}

This report summarizes the use of the Prickett and Lonnquist two-dimensional groundwater model, which has been programmed for the Apple II minicomputer. Both leaky and nonleaky confined aquifers can be simulated. The model was adapted from the FORTRAN version of Prickett and Lonnquist. 1 Additional information on the model and some advice on its use can be found in Reference 1 . In the configuration presented here, the program requires $64 \mathrm{~K}$ bits of memory. Because of the large number of arrays used in the program, and memory limitations of the Apple II, the maximum grid size that can be used is 20 rows by 20 columns. Input to the program is interactive, with prompting by the computer. Output consists of predicted head values at the row-column intersections (nodes).

Funding for this project was provided by the Low-to-Moderate Temperature Reservoir Engineering Program, Department of Energy, supervised at EG\&G Idaho by Max R. Dolenc. Steve A. Mizell of the Geosciences Branch, EG\&G Idaho, provided assistance in adapting the program to the Apple II minicomputer. 
NUMERICAL MODEL

On a microscopic scale, flow in a porous medium occurs along tortuous paths through various pore spaces. The direction and velocity of flow through each pore can be different. For a homogeneous medium, if direction and velocity are averaged over increasing numbers of pores (that is, over a larger volume of aquifer), a stable estimate of mean flow direction and velocity will be obtained once a certain minimum aquifer volume is exceeded. ${ }^{2}$ This minimum aquifer volume is termed the representative elementary volume (REV). The minimum size of the REV will depend on the size, shape, orientation, and packing of grains. There will be a maximum REV in nonhomogeneous aquifers, where aquifer characteristics change spatially. The node spacing in a finite difference model must be selected so that aquifer characteristics are adequately represented. In this adaptation of the Prickett and Lonnquist model, the limited number of nodes requires a very coarse grid spacing when large areas are to be simulated. Thus, only major nonhomogeneities in aquifer properties can be represented. Also, because the model is a horizontal two-dimensional model, vertical differences in aquifer characteristics are averaged into a single aquifer parameter.

The equations used in the numerical simulation are based on the principle of conservation of mass. The mass of water leaving a nodal volume must be equal to the amount of water entering, plus or minus any changes in storage, plus or minus any external additions or subtractions of water (such as pumpage). This can be expressed by Equation (1), with subscripts referenced to Figure 1.

$\mathrm{Q}_{1}+\mathrm{Q}_{3}=\mathrm{Q}_{2}+\mathrm{Q}_{4} \pm \mathrm{Q}_{\mathrm{s}} \pm \mathrm{Q}_{\mathrm{p}}$

where

$$
\begin{aligned}
& \mathrm{Q}_{1}+\mathrm{Q}_{3}=\text { inflow to nodal volume } \\
& \mathrm{Q}_{2}+\mathrm{Q}_{4}=\text { outflow from nodal volume } \\
& \mathrm{Q}_{\mathrm{S}} \quad=\text { addition to or subtraction } \\
& \text { from storage } \\
& \mathrm{Q}_{\mathrm{p}} \quad=\text { other changes in water } \\
& \text { volume, such as pumpage } \\
& (-) \text { or injection }(+) \text {. }
\end{aligned}
$$

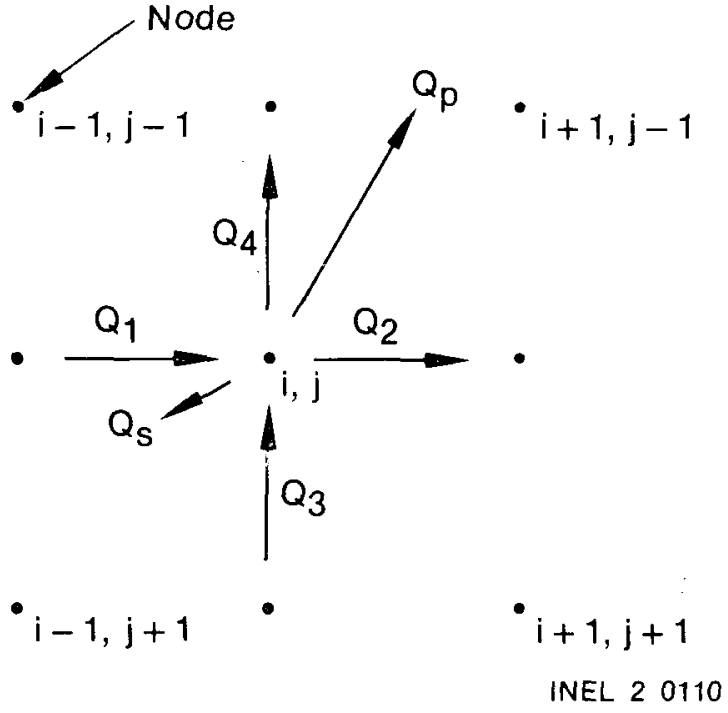

Figure 1. Finite difference grid showing flow volume relations.

For flow in the aquifer, $\mathrm{Q}_{1}$ through $\mathrm{Q}_{4}$, Darcy's law can be used to calculate the flow volumes. Darcy's law states that the discharge through a unit width of aquifer is related to the ability of the aquifer to transmit water (the transmissivity, T), and the change in head with distance.

$Q=T \frac{\partial h}{\partial x} \Delta y$

where

$$
\begin{aligned}
& \frac{\partial h}{\partial x}=\text { head gradient or rate of change of } \\
& \text { - } \Delta y=\text { width } \\
& \mathrm{Q}=\text { discharge. }
\end{aligned}
$$

The transmissivity is the amount of water that can be passed through a unit width of aquifer under a unit head gradient. It is related to the hydraulic conductivity $(\mathrm{K})$ by $\mathrm{T}=\mathrm{K} \cdot \mathrm{m}$, where $m$ is aquifer thickness. Therefore, the transmissivity is a vertical average of aquifer permeability, and depends on aquifer thickness. 
Using Equation (2) to calculate $\mathrm{Q}_{1}$ through $\mathrm{Q}_{4}$ in Equation (1) gives the following relationships.

$$
\begin{aligned}
& Q_{1}=T_{i-1, j, 2} \cdot \Delta y \cdot \frac{\left(h_{i-1, j}-h_{i, j}\right)}{\Delta x} \\
& Q_{2}=T_{i, j, 2} \cdot \Delta y \cdot \frac{\left(h_{i, j}-h_{i}+1, j\right)}{\Delta x} \\
& Q_{3}=T_{i, j+1,1} \cdot \Delta x \cdot \frac{\left(h_{i, j}+1-h_{i, j}\right)}{\Delta y} \\
& Q_{4}=T_{i, j, 1} \cdot \Delta x \cdot \frac{\left(h_{i, j}-h_{i, j-1}\right)}{\Delta y} .
\end{aligned}
$$

The change in storage $\left(Q_{S}\right)$ is given by the relation

$Q_{s}=S \cdot \Delta x \cdot \Delta y \frac{\left(h_{i, j}-h^{\prime}{ }_{i, j}\right)}{\Delta t}$ where

$$
\begin{aligned}
\mathrm{S}= & \begin{array}{l}
\text { ratio storage coefficient (volume/ } \\
\text { volume) }
\end{array} \\
\mathrm{t}= & \text { time } \\
\mathrm{h}^{\prime}{ }_{\mathrm{i}, \mathrm{j}}= & \begin{array}{l}
\text { head at node } \mathrm{i}, \mathrm{j} \text { at a previous time } \\
\text { given by } \mathrm{t}-\Delta \mathrm{t} .
\end{array}
\end{aligned}
$$

External volume changes, such as from pumpage, must be known explicitly. Other Q's are possible, such as from evapotranspiration or leakage. For explanation of how these parameters are added to the model, refer to Reference 1.

Replacing the Q's in Equation (1) with Equations (3a) through (3d) and (4) gives a finite difference approximation of flow through a porous medium. An equation of the same form exists for each node in the model, and these must be solved simultaneously to determine the head distribution in the aquifer. This series of equations is solved using an iterative alternating direction implicit technique. ${ }^{1}$ 


\section{VERIFICATION}

Results generated by a numerical model must be verified to assure that they are meaningful. This adaptation of the Prickett and Lonnquist model was verified by comparing numerical solutions from the model with analytical solutions. The configuration of the model used for verification is shown pictorially in Figure 2. Table 1 gives the parameters input to the model. A single pumping well was placed at the center of a grid of sufficient size to assure that boundary effects would not influence the calculations.

Analytical solutions for nonleaky conditions were calculated using Equation (5) and hydrologic parameters given in Table 1 .

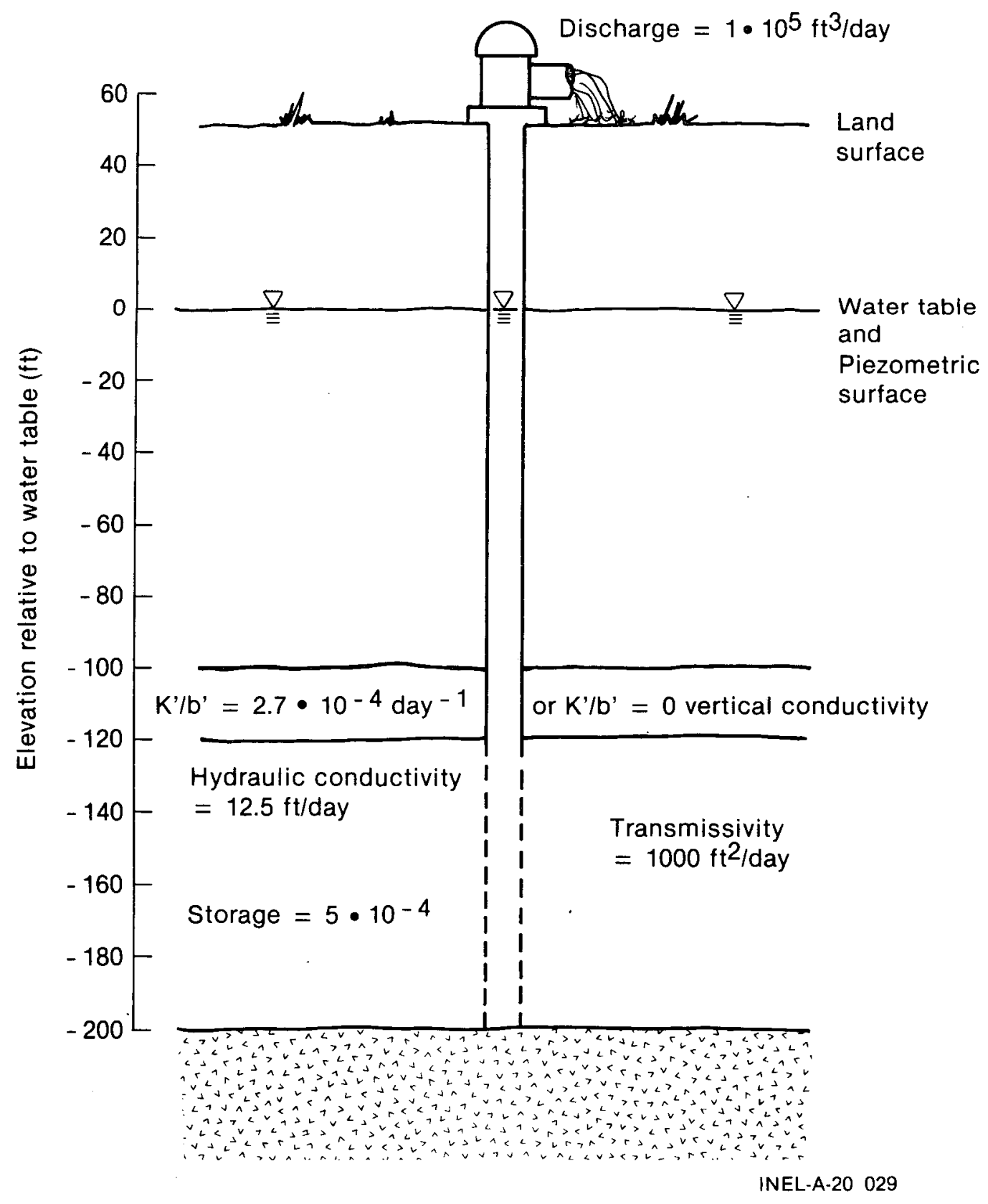

Figure 2. Schematic of aquifer system used to validate the computer code. 
Table 1. Configuration of model for validation runs

MODEL DESCRIPTION

STEPS $\ldots \ldots \ldots \ldots \ldots \ldots, 10$

COLUMNS ............. 19

ROWS ............... 19

DELTA $T \ldots \ldots \ldots \ldots \ldots . \ldots . \ldots . \ldots . \ldots$

ERROR $\ldots \ldots \ldots \ldots \ldots \ldots, 3$

DEFAULT PARAMETERS

TRANSMSSVTY ......... 1000

STORAGE $\ldots \ldots \ldots \ldots \ldots \ldots$ 5E-04

HEADS $\ldots \ldots \ldots \ldots \ldots \ldots . \ldots$

PUMPAGE $\ldots \ldots \ldots \ldots \ldots \ldots, 0$

VERT COND ............ 2.7E-04

SOURCE BED ........... 0

GRIDS .............. 1000

\section{VARIABLE GRID SPACINGS}

$\begin{array}{rr}\text { X SPACING } & \text { Y SPACING } \\ 10000 & 10000 \\ 7500 & 7500 \\ 5000 & 5000 \\ 3000 & 3000 \\ 1000 & 1000 \\ 500 & 500 \\ 300 & 300 \\ 100 & 100 \\ 100 & 100 \\ 100 & 100 \\ 100 & 100 \\ 300 & 300 \\ 500 & 500 \\ 1000 & 1000 \\ 3000 & 3000 \\ 5000 & 5000 \\ 7500 & 7500 \\ 10000 & 10000\end{array}$

LOCATIONS OF PUMPING WELLS

PUMPAGE

COLUMN

ROW

100000

10

10 $\mathrm{s}=\frac{2.3 \mathrm{Q}}{4 \pi \mathrm{T}} \log \frac{2.25 \mathrm{Tt}}{\mathrm{r}^{2} \mathrm{~S}}$

where

$$
\begin{aligned}
& \mathrm{S}=\text { drawdown } \\
& \mathrm{Q}=\text { discharge of pumped well } \\
& \mathrm{T}=\text { transmissivity } \\
& \mathrm{t}=\text { time } \\
& \mathrm{r}=\text { distance from pumped well } \\
& \mathrm{S}=\text { storage coefficient. }
\end{aligned}
$$

The drawdown as a function of distance from the pumped well after 10 days of pumping is shown in Figure 3. Equation (5) is applicable to a limited range of times and distances. At a given distance from the pumped well, there is a minimum time that must pass before the assumptions inherent in Equation (5) are valid. For nonleaky artesian conditions, this time is given by the relation

$t=\frac{12.533 r^{2} S}{T}$

where

$$
\begin{aligned}
& \mathrm{t}=\text { days } \\
& \mathrm{r}=\text { feet } \\
& \mathrm{T}=\mathrm{ft}^{2} / \text { day } \\
& \mathrm{S}=\mathrm{a} \text { fraction }
\end{aligned}
$$

and where the indicated units must be used for consistency with the constant in the equation. For a time of 10 days, simulated drawdowns beyond $1263 \mathrm{ft}$ will not be strictly comparable to values given by Equation (5). For greater distances and leaky artesian conditions, analytical solutions were obtained using the Theis equation, as described by Lohman. 3

Comparison of drawdowns from the analytical and numerical solution methods for both time and distance drawdown (Tables 2 and 3) show 


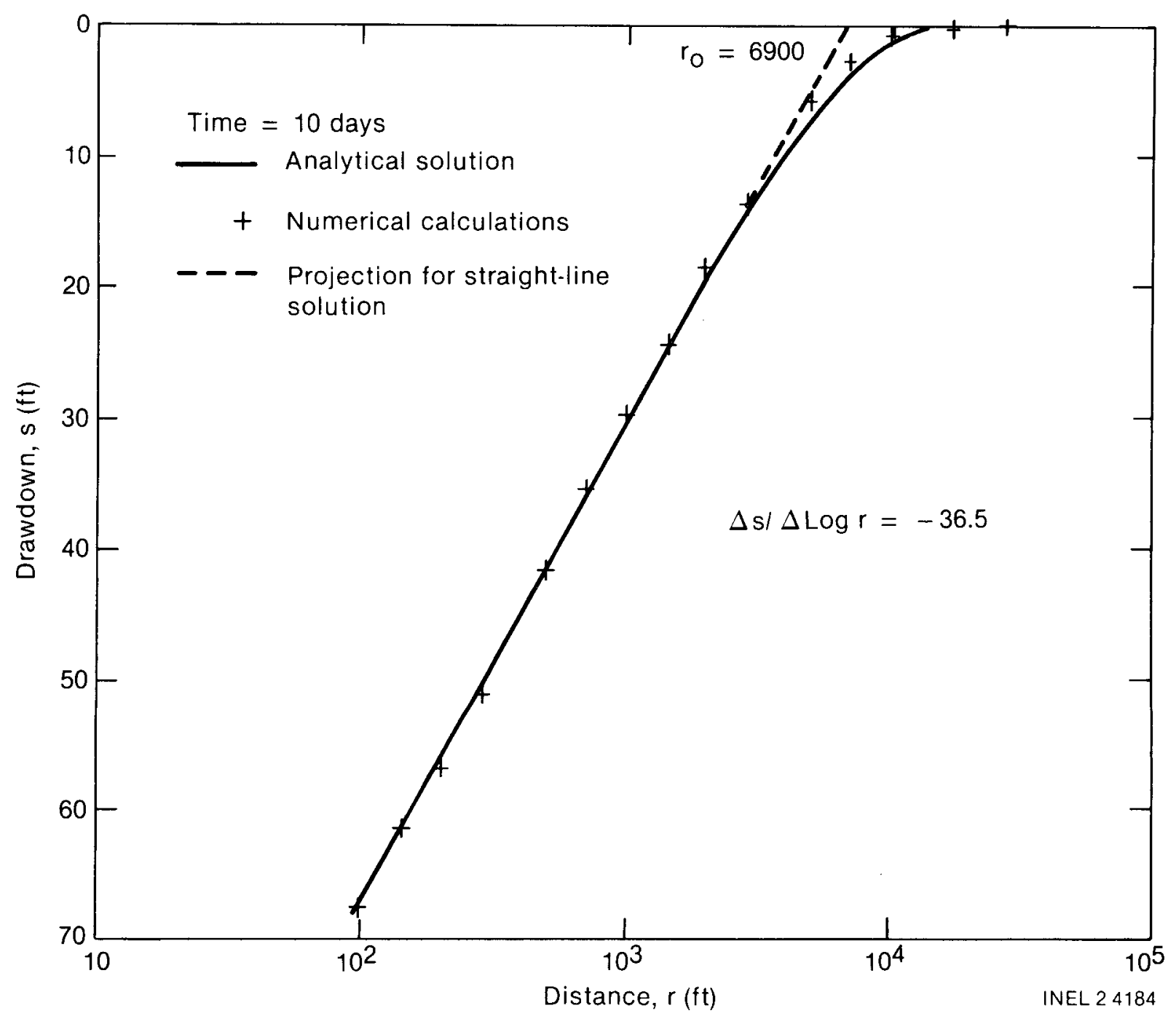

Figure 3. Plot of distance versus drawdown for nonleaky aquifer simulation after a time of 10 days.

reasonable agreement. Using straight-line plots for nonleaky conditions (Figure 3 ) and type-curve matching for leaky conditions (Figure 4), aquifer parameters were estimated from output of the numerical simulations. For nonleaky conditions, transmissivity was calculated from Figure 3 and the equation

$\mathrm{T}=-\frac{2.3 \mathrm{Q}}{2 \pi(\Delta \mathrm{s} / \Delta \log \mathrm{r})}$

and storage from

$$
\mathrm{S}=2.25 \mathrm{~T}\left(\frac{\mathrm{t}}{\mathrm{r}_{\mathrm{o}}^{2}}\right) \text {. }
$$

For leaky conditions, the points in Figure 4 were matched to type curves given by Lohman. ${ }^{3}$ Parts of the curves for $\mathrm{v}=0.02$ and $\mathrm{v}=0.05$ are shown. From this it was concluded that 0.03 was the best estimate for $\mathrm{v}$. The match point was selected and the values shown in Figure 4 used to calculate aquifer parameters using

$\mathrm{T}=\frac{\mathrm{Q}}{4 \pi \mathrm{s}} \mathrm{W}(\mathrm{u}, \mathrm{r} / \mathrm{b})$

for transmissivity and 
Table 2. Comparison of analytical and numerical values for time-drawdown at a distance of $100 \mathrm{ft}$

\begin{tabular}{|c|c|c|c|}
\hline \multirow[b]{2}{*}{$\begin{array}{l}\text { Time } \\
\text { (d) }\end{array}$} & \multicolumn{2}{|c|}{$\begin{array}{c}\text { Drawdown } \\
(\mathrm{ft})\end{array}$} & \multirow{2}{*}{$\begin{array}{c}\text { Difference } \\
\quad(\%)\end{array}$} \\
\hline & Analytical & Numerical & \\
\hline \multicolumn{4}{|l|}{ Nonleaky } \\
\hline $\begin{array}{r}2.9 \\
3.8 \\
5.0 \\
6.4 \\
8.0 \\
10.0\end{array}$ & $\begin{array}{l}-56.9 \\
-59.2 \\
-61.3 \\
-63.3 \\
-65.1 \\
-66.9\end{array}$ & $\begin{array}{l}-56.4 \\
-58.9 \\
-61.3 \\
-63.7 \\
-66.0 \\
-68.2\end{array}$ & $\begin{array}{r}1.0 \\
0.6 \\
0.0 \\
-0.7 \\
-1.5 \\
-2.0\end{array}$ \\
\hline \multicolumn{4}{|l|}{ Leaky } \\
\hline $\begin{array}{r}1.4 \\
2.3 \\
3.6 \\
5.5 \\
8.2 \\
10.0\end{array}$ & $\begin{array}{l}-46.2 \\
-47.6 \\
-48.4 \\
-48.7 \\
-48.8 \\
-48.8\end{array}$ & $\begin{array}{l}-46.0 \\
-47.9 \\
-48.9 \\
-49.3 \\
-49.5 \\
-49.5\end{array}$ & $\begin{array}{r}0.4 \\
-0.6 \\
-1.0 \\
-1.3 \\
-1.4 \\
-1.5\end{array}$ \\
\hline
\end{tabular}

a. Percentage difference is defined as:

$\frac{\text { Analytical - Numerical }}{\text { Analytical }} 100$.

Table 3. Comparison of analytical and numerical values for distance-drawdown at a time of 10 days

Drawdown

(ft)

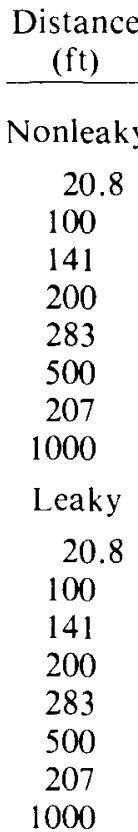

Analytical $\quad$ Numerical

Difference

$(\%)$

$-91.8$

$-68.9$

$-61.4$

$-55.8$

$-50.3$

$-41.3$

$-35.8$

$-30.3$

$-93.3$

$-68.2$

$-61.5$

$-56.8$

$-51.1$

$-41.5$

$-35.6$

$-29.8$

$-1.5$

$-2.1$

$-0.1$

$-1.7$

$-1.4$

$-0.6$

0.5

1.5

Leaky

$-73.8$

$-49.0$

$-43.6$

$-38.6$

$-32.3$

$-24.0$

$-18.9$

$-14.2$

$-74.5$

$-0.9$

$-49.5$

$-1.2$

$-42.8$

$-38.2$

$-32.6$

1.8

1.1

$-23.5$

$-18.2$

$-13.2$

$-0.8$

2.0

3.7

7.0 


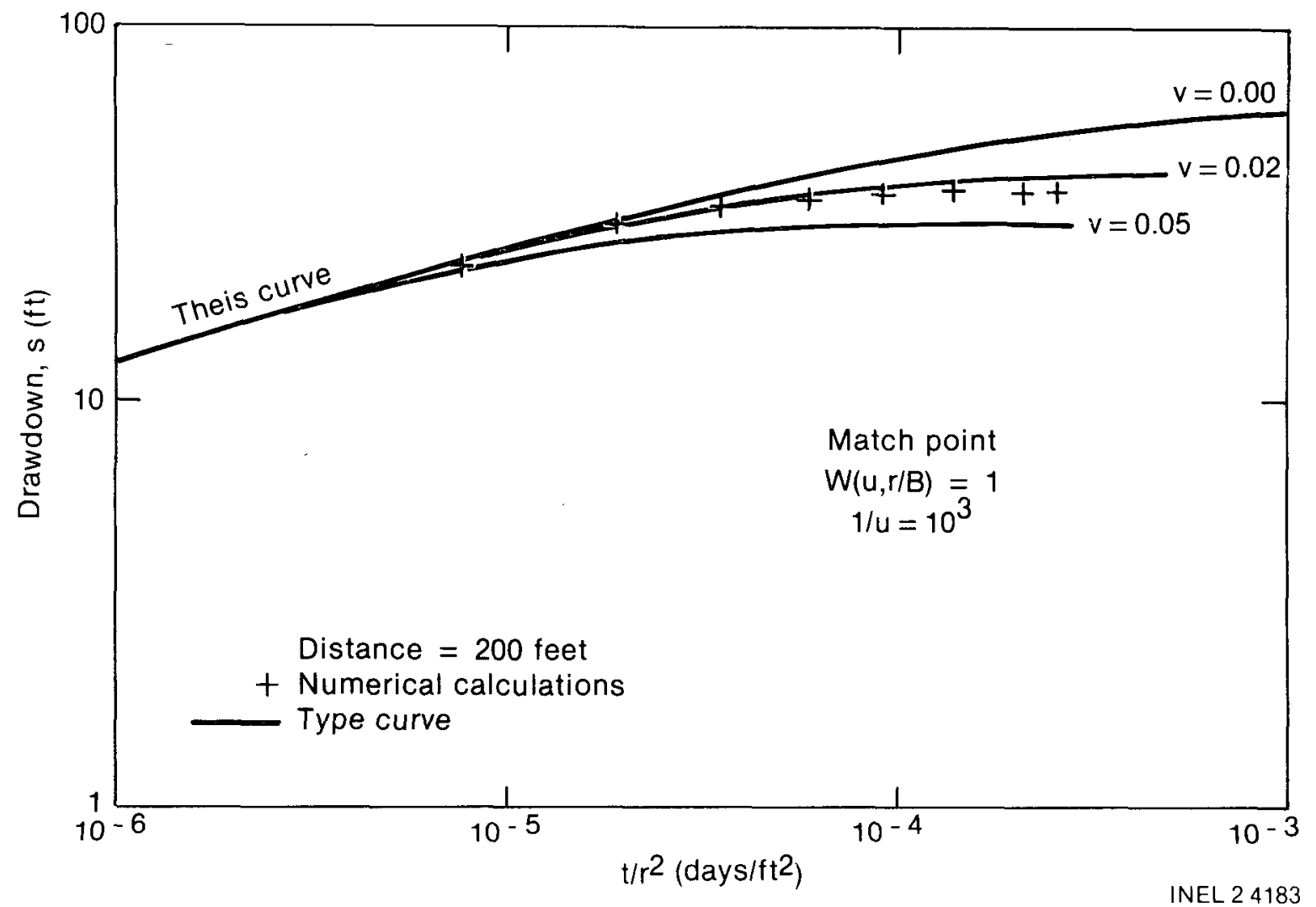

Figure 4. Comparison of simulated drawdown data at a distance of $200 \mathrm{ft}$ to the type curve for leaky artesian aquifers.

for storage. Leakage was calculated from

$K^{\prime} / b^{\prime}=4 T \frac{v^{2}}{r^{2}}$.

Input and estimated values for transmissivity (T), storage (S), and vertical hydraulic conductivity $\left(\mathrm{K}^{\prime} / \mathrm{b}^{\prime}\right)$ are shown in Table 4 . The parameters calculated from the numerical solutions show very close agreement to transmissivity, storage coefficient, and leakage initially input to the model.

Simulation runs produce reasonably accurate head distributions. Two factors that probably contribute to the observed discrepancies are problems in scaling aquifer coefficients for variable grid spacings, and numerically approximating the solution to analytical equations. Because of the relatively small grid size possible with the minicomputer, the model is best used for simulations of small areas. 
Table 4. Comparison of hydrologic parameters ${ }^{a}$

\begin{tabular}{|c|c|c|c|c|c|}
\hline & \multicolumn{3}{|c|}{ Leaky } & \multicolumn{2}{|c|}{ Nonleaky } \\
\hline & $\begin{array}{c}\begin{array}{c}\mathrm{T} \\
\left(\mathrm{ft}^{2} / \mathrm{d}\right)\end{array} \\
\end{array}$ & $\mathrm{S}$ & $\begin{array}{l}\mathrm{K}^{\prime} / \mathrm{b}^{\prime} \\
\left(\mathrm{d}^{-1}\right)\end{array}$ & $\begin{array}{c}\mathrm{T} \\
\left(\mathrm{ft}^{2} / \mathrm{d}\right)\end{array}$ & $S$ \\
\hline $\begin{array}{l}\text { Model } \\
\text { parameter }\end{array}$ & 1000 & $5 \cdot 10^{-4}$ & $2.7 \cdot 10^{-4}$ & 1000 & $5 \cdot 10^{-4}$ \\
\hline $\begin{array}{l}\text { Numerical } \\
\text { solution }\end{array}$ & 1190 & $4.8 \cdot 10^{-4}$ & $1 . \therefore \cdot 10^{-4}$ & 1006 & $4.8 \cdot 10^{-4}$ \\
\hline
\end{tabular}

a. Analyses for leaky conditions were performed by type-curve matching and for nonleaky conditions by the straight-line method. 


\section{PROGRAM USE}

Input to the model is in two stages. The first stage is for input of model parameters and default hydrologic parameters. Default hydrologic parameters are assigned to each node, so that all nodes have equal values of transmissivity, storage, etc. The second stage of input is for modifying individual parameters for a node or for subareas within the model, and for changing the grid spacing.

The units must be internally consistent for proper use. Unit combinations of $\mathrm{gal} / \mathrm{day} / \mathrm{ft}$, $\mathrm{ft}^{3} / \mathrm{day} / \mathrm{ft}, \mathrm{m}^{3} / \mathrm{s} / \mathrm{m}$, are all equally valid. For example, if transmissivity is given in $\mathrm{m}^{2} / \mathrm{s}$, the time increment must be in seconds and heads in meters. Input variables in the following list are labeled as to the unit combinations. The letters symbolize: $\mathrm{t}$-time ( $\mathrm{min}, \mathrm{d})$; $\mathrm{L}$-length ( $\mathrm{ft}, \mathrm{m}$ ); $\mathrm{v}$-volume $\left(\mathrm{gal}, \mathrm{ft}^{3}, \mathrm{~m}^{3}\right)$.

The input variables, in order of appearance are:

1. Number of steps-The number of time steps that are simulated by the model. The time duration modeled is a function of the time increment and the number of steps. At least six time steps should precede the time period for which head values are desired. Large numbers of steps will require large amounts of time; simulation of a $19 \mathrm{x}$ 19 grid required $0.5 \mathrm{~h}$ of real time per time step.

2. Time increment $(\Delta t)-T$ The time increment increases by a factor of 1.2 with each time step. This results in more stable solutions for early time steps and still allows later time steps to simulate longer time periods.

3. Error check (L)-The maximum permissible error for testing convergence. To calculate this value, use:

Error $=(\mathrm{Q} \cdot \Delta \mathrm{t}) /(10 \cdot \mathrm{S} \cdot \Delta \mathrm{x} \cdot \Delta \mathrm{y})$

where

$$
\begin{aligned}
& \mathrm{Q}=\begin{array}{l}
\text { well discharge summed over all } \\
\text { nodes }
\end{array} \\
& \Delta \mathrm{t}=\text { time increment }
\end{aligned}
$$

$$
\begin{aligned}
& \mathrm{S}=\text { storage coefficient } \\
& \Delta \mathrm{x}=\begin{array}{l}
\text { geometric mean of largest and } \\
\text { smallest } \mathrm{x} \text { grid spacing }
\end{array} \\
& \Delta \mathrm{y}=\begin{array}{l}
\text { geometric mean of largest and } \\
\text { smallest } \mathrm{y} \text { grid spacing. }
\end{array}
\end{aligned}
$$

Units must be consistent to give error in units of length.

4. Number of columns-must be $\leq 20$.

5. Number of rows-must be $\leq 20$.

6. Transmissivity, $(\mathrm{v} / \mathrm{t} / \mathrm{L})$ or $\left(\mathrm{L}^{2} / \mathrm{t}\right)-\mathrm{The}$ volume of water transported through unit width of aquifer, per unit time, under unit hydraulic gradient. The program automatically compensates for variable grid spacings. Same value is used for both $\mathrm{x}$ and y directions.

7. Storage, (ratio) or $\left(\mathrm{v} / \mathrm{L}^{3}\right)$ - The storage coefficient with units depending on the volume measurement system. If volume is measured as $\mathrm{L}^{3}$, then the ratio storage coefficient is used. If volume is measured as $v$ (liters, gal) then the storage coefficient must be multiplied by the conversion factor for $\mathrm{v}$ to $\mathrm{L}^{3}$. For example, $7.48 \mathrm{gal} / \mathrm{ft}^{3}$ or 1000 liters $/ \mathrm{m}^{3}$. The effects of grid spacing are taken into account by the model.

8. Heads (L)-The elevation of the piezometric surface for the confined aquifer relative to some arbitrary datum.

9. Pumpage, $(\mathrm{v} / \mathrm{t})$ or $\left(\mathrm{L}^{3 / \mathrm{t}}\right)$-Discharge from $(+)$ or recharge to $(-)$ a node. The rate is held constant throughout all time steps.

10. Grid spacing (L)-Default distance between nodes if all distances are equal.

11. Vertical conductivity, $\left(\mathrm{v} / \mathrm{t} / \mathrm{L}^{3}\right)$ or $(1 / \mathrm{t})-$ Volume of water transported through unit area of confining bed, per unit time, under unit head differential divided by the thickness of the confining bed. The model 
takes care of determining the volume of leakage by adjusting for the grid spacing.

12. Source bed heads (L)-The elevation of water in the source bed, for leaky conditions, relative to the same datum as the piezometric surface.

The second stage of input to the model allows modification of the default parameters. The possible changes are listed on the screen, and the selection made by number. When no further changes are desired, exit by typing zero. Modifications to hydrologic parameters can be made either to a range of nodes, or to a series of individual nodes. By changing hydrologic parameter values for certain nodes, recharge boundaries, constant head boundaries, or highly transmissive fault zones can be simulated.

The final alteration that can be made is to change the grid spacing. This is done by entering the distance between adjacent nodes, not the width of the nodal areas. The program will then adjust the hydrologic parameters for the different grid size. More detail can be obtained by placing smaller grids near pumping wells and other areas where heads are changing rapidly.
For extensive hydrologic variables (storage, vertical conductivity), the nodal areas are calculated using arithmetic means. For intensive hydrologic variables (transmissivity), the adjusted nodal values are calculated using harmonic means. ${ }^{4}$

For equidimensional grids, the number of nodes increases as the square of the number of rows (or columns), and so the time required for simulation runs increases greatly with increasing grid size. A simulation of a $19 \times 19$ grid, for verification purposes, required about $4 \mathrm{~h}$ for 10 time steps.

Appendix $\mathrm{A}$ is an example of the output from a short simulation run of a $5 \times 5$ grid. The first page is a printout of the default parameters. If variable grid spacings or pumping wells are added, these are also printed out. Nonleaky conditions can be simulated by setting the vertical conductivity to zero. A listing of the hydrologic parameters for the nodes, corrected for grid spacing, can be obtained as an option. The remaining output consists of head values at the nodes for each time step.

Appendix B contains a listing of the program. 


\section{REFERENCES}

1. T. A. Prickett and C. G. Lonnquist, Selected Digital Computer Techniques for Ground-Water Resource Evaluation, Illinois State Water Survey Bulletin 55, Urbana, Illinois, 1971.

2. J. Bear, Dynamics of Fluids in Porous Media, New York: American Elsevier Publishing Co., 1972.

3. S. W. Lohman, Ground-Water Hydratics, U.S. Geological Survey Professional Paper 708, 1972.

4. P. C. Trescott, G. F. Pinder, S. P. Larson, Finite-Difference Model for Aquifer Simulation in Two Dimensions with Results of Numerical Experiments, Techniques of Water-Resources Investigations of the U.S. Geological Survey, Book 7, Chapter C1, 1976. 


\section{APPENDIX A}

\section{EXAMPLE PROGRAM OUTPUT}




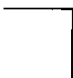




\section{APPENDIX A}

\section{EXAMPLE PROGRAM OUTPUT}

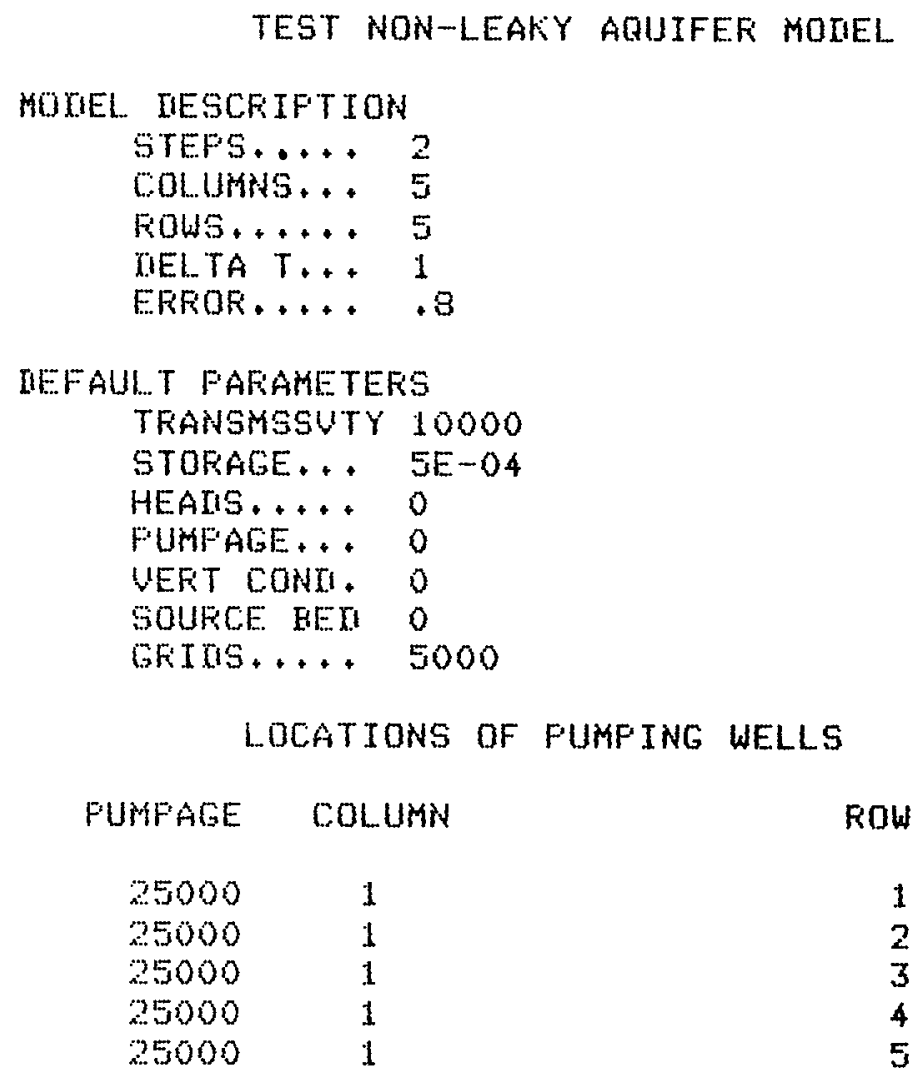


TFANSMISSIUITTY(C,R, 1)

$\begin{array}{lllll}\text { ROWS } & 1 & 2 & 3 & 4 \\ 1 & 10000 & 10000 & 10000 & 10000 \\ 2 & 10000 & 10000 & 10000 & 10000 \\ 3 & 10000 & 10000 & 10000 & 10000 \\ 4 & 10000 & 10000 & 10000 & 10000 \\ 5 & 10000 & 10000 & 10000 & 10000 \\ \text { ROWS } & 5 & 6 & 7 & 8 \\ 1 & 10000 & 0 & 0 & 0 \\ 2 & 10000 & 0 & 0 & 0 \\ 3 & 10000 & 0 & 0 & 0 \\ 4 & 10000 & 0 & 0 & 0\end{array}$

TRANSHTSSIUITTY(C,R,2)

ROW
1
2
3
4
5

Rous

1
2
3
4
5

STORAGE FACTORS
1

10000 10000 10000 10000 10000

5

10000 10000 10000 10000 10000
2

10000 10000 10000 10000 10000

6

0

0

0

0

0
3

10000 10000 10000 10000 10000

7

0

0

0

0

0
4

10000 10000 10000 10000 10000

8

0

0

0

0

0

$\begin{array}{ll}\text { Rows } & 1 \\ 1 & 12500 \\ 2 & 12500 \\ 3 & 12500 \\ 4 & 12500 \\ 3 & 12500 \\ \text { ROWS } & 5 \\ 1 & 12500 \\ 2 & 12500 \\ 3 & 12500 \\ 4 & 12500 \\ 5 & 12500\end{array}$

2

12500 12500 12500 12500 12500

6

0

0

0

0
3

12500

12500

12500

12500

12500

7

0

0

0

0
4

12500 12500 12500 12500 12500

8

0

0

0

0 


$$
\text { STEF }=1 \text { TIME }=1 \quad \text { *ITEF }=3 \underset{\text { ERFOR }=.120917802}{\text { COLUMN NUMEERS }}
$$

$\begin{array}{lllll}\text { kOWS } & 1 & 2 & 3 & 4 \\ 1 & -1.31 & -.45 & -.16 & -.05 \\ 2 & -1.31 & -.45 & -.16 & -.05 \\ 3 & -1.31 & -.45 & -.16 & -.05 \\ 4 & -1.31 & -.45 & -.16 & -.05 \\ 5 & -1.31 & -.45 & -.16 & -.06\end{array}$

$\begin{array}{lllll}\text { ROWS } & 5 & 6 & 7 & 8 \\ 1 & -.02 & 0 & 0 & 0 \\ 2 & -.02 & 0 & 0 & 0 \\ 3 & -.02 & 0 & 0 & 0 \\ 4 & -.02 & 0 & 0 & 0 \\ 5 & -.02 & 0 & 0 & 0\end{array}$

$$
\text { STEF }=2 \quad \text { TIME }=2.2 \quad \text { ITER }=3 \quad \underset{\text { COLUMN NUMRERS }}{\text { ERROR }=} .0789722348
$$

$\begin{array}{lllll}\text { ROUS } & 1 & 2 & 3 & 4 \\ 1 & -2.44 & -1.12 & -.49 & -.22 \\ 2 & -2.44 & -1.12 & -.49 & -.22 \\ 3 & -2.44 & -1.12 & -.49 & -.22 \\ 4 & -2.44 & -1.12 & -.49 & -.22 \\ 5 & -2.44 & -1.12 & -.49 & -.22\end{array}$

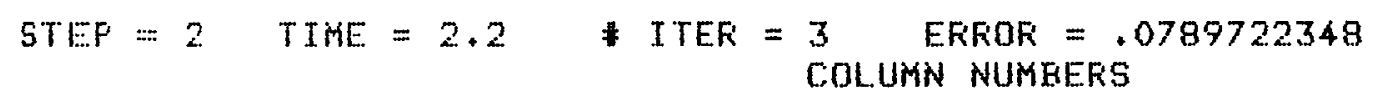

$\begin{array}{lllll}\text { RowS } & 5 & 6 & 7 & 8 \\ 1 & -.12 & 0 & 0 & 0 \\ 2 & -.12 & 0 & 0 & 0 \\ 3 & -.12 & 0 & 0 & 0 \\ 4 & -.12 & 0 & 0 & 0 \\ 5 & -.12 & 0 & 0 & 0\end{array}$


APPENDIX B

PROGRAM LISTING 


\section{APPENDIX B}

\section{PROGRAM LISTING}

10 IItH $H(20,20), H 0(20,20), 5 F(20,20), Q(20,20), T(20,20,2), \mathrm{B}(20), 6(20), I L(20$ $, 20), U \pi(10), \times(20), Y(20), \operatorname{IHH}(20,20), N 1(15), F 1(20,20), F 2(20,20)$

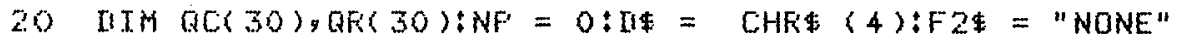

30 IIATA "HEAIIS" "TFANS X" "TFANS Y" "STORAGE" "FUMFAGE" "GFIIIS" "VEFT CONII" "SOURCE HEAI"

40 FOR $I=1$ TO 8: FEAII WIL(I): NEXT I: IIEF FN MOIKA) = INT (AA/2-INT $(A, 2)) * 2 .+0.5)$

50 IIATA $2,1,8,5,5,10000, .0005,0,0,5000,0,0$

$60 \mathrm{FOF} I=1$ TO $12:$ FEAII N1(I): NEXT I:UN $=1$

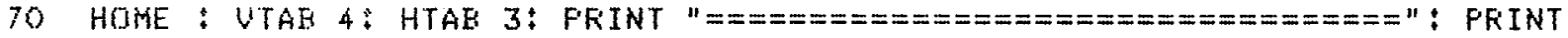
TAEY 3)"FRICKETT ANII LONNQUIST TWO-I MOIEL" : FRINT TAE( 3 )" $=======$

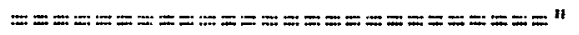

80 UTAE 10: FFINT TABC 5)"CONTACT S.A. HIZELL OK L.C. HULL": FRINT TAER 5 )"OF THE GEOSCIENCES HFANCH FOR": FFINT TAES 5)"FURTHER IETAILS ON ITS USE." : UTAE 23: FFINT "FFESS YFTNO TO CONTINUE" : GET A\$

90 HOME : UTAF 5 : FRINT "ENTEF TITLE FOF FFOELEM. . " : FRINT : INFUT " "ITI TLE\$

100 HOHE : INUERSE : HTAE 3: FFINT "IIATA ENTKY": NOFMAL : VTAE 1 : HTAB 14 " FFTNT "- ENTER THE FOLLOWING" : HTAB 16 : FRINT "FAFAMETEFS ANI" : HTAE 16: FFINT "IEFAULT VALUES"

110 FRINT :I = 1 : FRINT "NUMEEF OF STEFS. + "N1(1): UTAE 5: HTAE 30: INFUT " N24: GOSUR 450: FFINT "IELTA TIME. (T) "\$N1(2): UTAE 6: HTAH 30: INPUT " "SN2": GOSUE 450

120 FRINT "ERFOF CHECK. (L) ";N1(3): UTAB 7 : HTAB 30: INFUT " ;N2\$: GOSUB 450: FFINT "NUHEEF COLUMNS $(<=20)$ "\$N1(4): UTAE 8: HTAB 30: INFUT " ; N24: GOSUE 450

130 FRTNT "NUMEEF FOWS $(<=20)$ "\$NI(5): UTAE 9: HTAE 30: INFUT " " N2\$: GOSUE 450 : FEINT "TFANSHSSUTY + (U/T/L) "\$N1(6): UTAE 10: HTAE 30: INFUT " N2A: GOSUE 450

140 FFINT "STORAGE... "\$N1(7): UTAE 11: HTAE 30! INFUT " " N2\$: GOSUH 450: FFTNT "HEAIS...(L). "AN1(8): UTAE 12: HTAE 30: INFUT " "N2\$: GOSUB 4 50

150 FRINT "FUMFAGE + +(U/T) " \$N1(9): UTAE 13: HTAE 30: INFUT " ;N2\$: GOSUE 450: FFINT "GFII SFACING. (L) "\$N1(10): UTAE 14: HTAB 30: INFUT " "IN 2): GOSUE 450

160 FFINT "VEFT CONI, + (U/T/L3) "FN1(11): UTAE 15: HTAE 30: INFUT " "N2\$: GOSUE 450: FFINT "SOURCE HEAIS. .(L) "\$N1(12): UTAE 16: HTAE 30: INFUT" "; N2\$: GOSUR 450

170 FRINT : FFINT: INFUT "HAKE ANY CHANGES ? $(Y / N)+"$ "Y\$: IF Y\$ = "Y" THEN 1.00

180 HOME : UTAE 10: HTAE 8: INUERSE : PRINT "INITIALIZING ARFAYS" : NORMAL

$190 N O=N(14) \div N R=N 1(5): X Y=N 1(10): 55=N 1(7): H H=N 1(8): Q Q=N 1(9): I T A$ $=N 1(2): N S=N 1(1): E I G=N 1(3) ! T T=N 1(6): \mathrm{RF}=N 1(11): \mathrm{FH}=N 1(12)$

200 FOF $I=1$ TO NC: FOF J $=1$ TONF:T(I,J,1)=N1(6):T(I,J,2)=N1(6):SF $(I, J)=S S * X Y * X Y: H O(I, J)=H H: H(I, J)=H H: Q(I, J)=Q Q: I L(I, J)=0$ $.0 \div I H(I, J)=H H: R I(I, J)=F F * X Y * X Y: F(2(I, J)=F H: N E X T J, I$

210 FOR $I=1$ TO NE $+1: X(I)=N 1(10): N E X T I: F O R J=1$ TO NF $+1: Y(J)=$ N1(JO): NEXT J

220 HOME : UTAE 2: HTAE 2: FFINT "IIO YOU UISH TO CHANGE THE IIEFAULT": HTAB 2: FFINT "UALUES FOF ANY NOIES?": FFINT : FRINT : HTAE 4 : FRINT "0... NO CHANGES" : FFINT TAE 4 )"1 + "HANGE. HEAIS" 
230 FRINT TAR 4 )"2. . CHANGE Y TFANSMSSUITY (T(C,R,1))": FRTNT TAF( 4)" $3 .$. . CHANGE $X$ TFANSMSSUTTY $(T(C, R, 2)) "$

240 FRINT TAK( 4)"4... CHANGE STOFATIUITY": FFINT TAK( 4)"5...CHANGE PUM FING RATES"

250 FRINT TAES 4 )"6. .CHANGE VERT CONIUCTIUITY": FRINT TAE( 4 )"7, ,CHAN GE SQUFCE HEAIIS"

260 FRINT TAES 4)"8. . CHANGE BOTH $X$ ANI Y TRANS"

270 FRINT : FRINT: HTAE 3 : INFUT "ENTER NUMEER OF CHANGE...";A1

280 IF $A 1=0$ THEN 650

290 HOME : UTAE 5: HTAE 5: FRINT "CHANGE A RANGE OR SERIES ?": HTAB 10: INPUT "(F/S).." \$N2 : IF N2" = "S" THEN 330

300 HOME : FRINT "ENTEF NEW VALUES ANI LOCATIONS": FRINT TAE( 6)" CRTN? T O ENI": PFINT : FRINT TAB( 3)"ENTER VALUE FOR " \$WT\$(A1): UTAB 6: HTAB 10: INFUT A3\$: IF $A 3 \$="$ "THEN 220

$310 \mathrm{~A}:=$ VAL $(A 3): R 4=2$

320 FRINT: FRINT TAEK 3 )"ENTER MINIMUM ANII MAXIMUM COORIINATES": INPUT " MIN COL. "ISC: INFUT" MIN FOW ";SR: INFUT" " MAX COL ";L. C: INPUT " MAX FOU "ILF: GOTO 360

3.30 HOME : FRINT TABL 5)"ENTER O, TO ENI": FRINT "COL, ", "ROH, "; "VALUE "— FFINT

34.0 INFUT LC,LF,A2: IF LC $=0$ THEN 220

$350 S C=L C: S F=L F: F 4=1$

360 ON A1 GOTO $370,380,380,400,410,420,430,440$

370 FOF KC $=5 C$ TO LC: FOR KR = SR TO LK:HO(KC,KR) = A2:H(KC,KR)=A2!UH( $K C, K F)=A 2:$ NEXT KR,KC: ON R4 GOTO 340,300

380 III $=1$ : IF $A 1=3$ THEN III $=2$

$390 \mathrm{FOK} K \mathrm{KC}=$ SC TO LC: FOF KK $=$ SF TO LR:T(KC,KR,II) = A2: NEXT KR,KC: ON Fi4 COTO 340,300

$400 \mathrm{FOR} K \mathrm{KC}=$ SC TO LC: FOR KK $=S F$ TO LF:SF(KC,KR) = AZ *XY *XY: NEXT KK Fi,KC: ON Fi GOTO 340,300

$410 \mathrm{FOF} K \mathrm{KC}=S C$ TO LC: $F O F K K=S F$ TO $L F: G(K C, K R)=A 2: N F=N F+1: Q C(N F)$ $=K C: Q R(N F)=K R:$ NEXT KF,KC: ON K4 GOTO 340,300

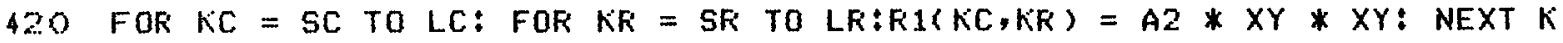
Fi,KE: ON Fit GOTO 340,300

$430 \mathrm{FOR} K C=S C$ TO LC: FOF KR = SF TO LR:R2(KC,KR ) = A2: NEXT KR,KC: ON R 4 GOTO 340,300

4.40 FOF KC $=S C$ TO LC: FOF KK $=S F$ TO LR: FOR KK = 1 TO $2: T(K C, K R, K K)=A$ 2: NEXT KK,KFi,KC: ON Fi4 GOTO 340,300

450 TF N2\$ $\% " \% "$ THEN N1(I) = VAL (N2\$)

$460 I=I+1:$ RETURN

470 REM SURROUTINE TO FRINT OUTFUT AFFAYS

180 FR\# 1: PRINT CHF士 (9): "80N"

490 FOR $K T=1$ TO NC STEF 4

500 FFINT "STEF = "IS;" TIME = " "TIME" \# ITER = "\$ITEF $=" ; E$

510 HTAF 35: FRINT "COLUHN NUMEERS" : FRINT

520 FRINT "ROWS",KT,KT + 1,KT + 2,KT + 3: FRINT

530 FOR $I=1$ TO NC: FOR J $=1$ TO NR: IF ABS (IH(I,J)-H(I,J)) .001 THEN 560

54.0 $T H=\operatorname{INT}(H(I, J) * 1 E 04): T 2=\operatorname{INT}(H(I, J) * 100) * .100 .:$ IF ABS (TT $1-T 2)>50.0$ THEN $T 1=T 1+100$

$550[(H(I, J)=I N T(T 1 / 100) / 100$

560 NEXT J,I

570 FOR KI $=1$ TO NR

580 FFINT KI, RHU(KT,KI), IHH(KT + 1,KI), IHKKT + 2,KI), IHKKT + 3,KI)

590 NEXT KI

600 FFINT CHFE (12)

610 NEXT KIT

620 FR\# O: RETURN

630 FIEM ENII FRINT ROUTINE 
640) FEM RESCALE AQUIFER COEFFICIENTS

650 HOME : UTAE $5:$ HTAB 2: PRINT "CHANGE GRID SFACINGS ?": PRINT : HTAE 5 : INPUT "ENTER Y OR $N$.. ";A2": IF A2\$ = "N" THEN 920

6SO HOME : FRINT "THERE ARE NC-1 IIISTANCES BETUEEN": PRINT TAER 8)"NC CO LUMNS": FOF $I=2$ TO NC: FRINT I - 1; TAB 4);X(I): INFUT XX $\$$ : GOSUB 790: NEXT I:X(1)=X(2):X(NC + 1)=X(NC)

670 HOME : PRINT "THERE ARE NR-1 IIISTANCES HETWEEN": PRINT TAR( 8 )"NR RO WS": FOR $J=2$ TO NR: FRINT $J-1$; TAER 4); $(J):$ INFUT YY\$: GOSUF 810 : NEXT J:Y(1) $=Y(2): Y(N R+1)=Y(N R)$

690 HOME : UTAE 5 : HTAE 5 : INFUT "MAKE ANY CHANGES $?(Y / N) " Y \$ \$$ IF $Y \$="$ Y" THEN 660

690 HOME : UTAE 8: HTAE 5: INUERSE : FRINT "SCALING AQUIFER COEFFICIENTS" INORMAL $:$ UN $=2$

700 FOR I = 1 TO NC: FOR $J=1$ TO NR:IIX $=(2 * X(I) * X(I+1)) /(X(I)+$ $X(I+1)):[Y=(2 * Y(J) * Y(J+1)) /(Y(J)+Y(J+1))$

$710 A X=(X(I)+X(I+1)) / 2 .: A Y=(Y(J)+Y(J+1)) / 2$.

$720 \mathrm{SF}(I, J)=(\mathrm{SF}(I, J) * A X * A Y) /(X Y * X Y): R 1(I, J)=(R 1(I, J) * A X * A Y$ ),$(X Y * X Y)$

$730 T(I, J, 1)=T(I, J, 1) * I X X /(Y(J+1))$

$740 T(I, J, 2)=T(I, J, 2) * U Y Y(X(I+1))$

750 NEXT $J, I$

760 GOTO 920

770 REM ENI RESCALING

780 REM FRINT COEFFICENT AFRAYS ANI HEAIINGS

790 IF $X X \$<"$ "THEN $X(I)=$ VAL $(X X \$)$

800 RETURN

810 IF YY\$ $\ "$ "THEN Y(J) = VAL (YY\$)

82:0 FETURN

830 FR\# 1: FRINT CHR (9);"8ON": FOR IT = 1 TO 2: PRINT : FRINT "TRANSMI SSIUITTY(C,R," "IT;")" " PRINT

8.9. FOR KT $=1$ TO NC STEF 4: PRINT : PRINT "ROWS",KT,KT + $1, K T+2, K T+3$ : FKINT

850 FOR KI = 1 TO NK: FRINT KI,T(KT,KI,IT),TKKT + 1,KI,IT),T(KT + 2,KI,IT , T KKT + 3,KI, IT ): NEXT KI,KT,IT

860 FFINT : FRINT "STORAGE FACTORS ": PRINT : FOR KT = 1 TO NC STEF 4 : PRINT : FRINT "ROWS",KT,KT + 1,KT + 2,KT + 3: FRINT

870 FOK KI = 1 TO NR: FFINT KI,SF(KT,KI), SF $(K T+1, K I), S F(K T+2, K I), S F(K$ $T+3, K I):$ NEXT KI,KT

880 SUM $=0.0:$ FOR $I=1$ TO NC: FOR $J=1$ TO NR:SUM $=$ SUM + RI $(I, J):$ NEXT I, I: IF SUM $=0.0$ THEN 910

890 FRINT : FRINT "UERTICLE CONIUCTIUITY " : FRINT \& FOR KT = 1 TO NC STEP 4: FRINT : FRINT "ROWS",KT,KT + 1,KT + 2,KT + 3ः PRINT

900 FOK $K I=1$ TO NR: FRINT KI,R1(KT,KI $, F 1(K T+1, K I), K 1(K T+2, K I), R 1(K$ $T+3, K I) \div$ NEXT KI,KT

910 FRINT CHF\$ (12): PR O: GOTO 930

920 HOME : UTAE 5: HTAE 9: FRINT "FRINT OUT ARRAYS ?" : UTAE 7: HTAE 13: INPUT $" Y / N)$. "IN2\$: IF N2\$ = "Y" THEN 830

930) FR\# 1: PRINT CHR (9):"80N": FRINT : FRINT TAER 15)TITLE\$: PRINT : PRINT

TAE( 5)"MONEL IIESCRIFTION ": PRINT TAEK 10)"STEPS..... " "NS: FRINT TAER (10)"COLUMNS... " "NC: PRINT TAER 10)"ROWS......" " ;NR: FRINT TAER 10)" MELTA T... "IIITA

940 PRINT TAES 10)"ERKOR..... "\$GIG: PRINT : PRINT TAE( 5)"IIEFAULT PAR AMETERS": FRINT TAE 10)"TRANSMSSUTY ":TT: PRINT TABI 10)"STORAGE.. - "SS: FRINT TAE( 10)"HEAIS..... ";HH: PRINT TAER 10)"FUMFAGE... " $\$$ QRQ

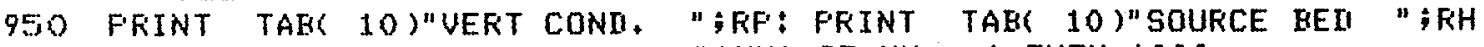

960 FRINT TAER 10)"GRIIIS..... ";XY: IF UN = 1 THEN 1000

970 FRINT : FRINT TAER 15)"VARIAELE GRIII SPACINGS": FRINT : FRINT TABR 8) "X SFACING"; TAE 17 ) "Y SFACING": FRINT 
$980 K T=N C:$ IF NR $>$ NC THEN KT $=$ NR

990 FOR KL = 2 TO KT: FRINT TABR 10)X(KL); TAE( 25)Y(KL): NEXT KL

1000 PRINT : FRINT TAE( 15)"LOCATIONS OF PUMFING WELLS" : FRINT : PRINT TAER 8)"FUMFAGE", TAE( 18)" COLUMN", TAEK 25)"ROW"! FRINT

1010 FOR $I=1$ TO NF: FFINT TAE( 10 )Q(QC(I), QR I )), TAE( 20)QC(I), TARK 27 ) QR ( I ): NEXT I

1020 FRTNT CHR $\$$ (12): FR

1030 IF NS $>14$ THEN 1040

$1032 \times 4=1: \mathrm{BH}=1:$ GOTO 1090

10.40 IF NS 221 THEN 1050

$10.42 \times 4=1: \mathrm{BH}=6:$ GOTO 1090

$1050 \times 4=2: \mathrm{BH}=6: 60 T 01090$

1060 REM

1070 REM AQUIFER MOIEL

1080 KEM

1090 TIME $=0:$ FOF IS $=1$ TO NS:TIME = TIME + IITA

1100 FOR $I=1$ TO NC: FOR $J=1$ TO NR:II=H(I,J) - HO(I,J):HO(I,J) $=H(I$, $J): F=1.0$

1110 IF IL(I,J) $=0.0$ THEN 1150

11. 20 IF IS $\gamma 2$ THEN $F=I /$ ILL $(I, J)$

1130 IF $F>5$ THEN $F=5$

11.40 IF $F \& 0$ THEN $F=0$

$1150 \mathrm{IL}(I, J)=U: H(I, J)=H(I, J)+I * F$ : NEXT J: NEXT I

1. 60 HOME : PRINT "STEF = "IS;" TIME = "\#TIME: PRINT : PRINT "ITER E FROR LIMIT": FFINT

11. 70 ITEF $=0$

$1180 \mathrm{E}=0.0$

$1190 \mathrm{ITEF}=\mathrm{ITER}+1$

1200 REM COLUMN CALCULATIONS

1210 FOR II $=1$ TO NC\$I =II: IF FN MOU( IS + ITER $)=1$ THEN I $=$ NC $-I+$ 1.

1220 FOF $J=1$ TO NR:ER $=S F(I, J) / U T A+R 1(I, J) \div[I I=H O(I, J) * S F(I, J) /$ $I T A-Q(I, J)+F(1(I, J) * R(2(I, J): A A=0.0: C C=0.0$

1230 IF $(J-1)=0$ THEN 1250

$12.40 A A=-T(I, J-1,1): B E=E B+T(I, J-1,1)$

1250 IF $(J-N R)=0$ THEN 1270

$1260 \mathrm{CC}=-\mathrm{T}(\mathrm{I}, \mathrm{J}, 1): \mathrm{EB}=\mathrm{EB}+\mathrm{T}(\mathrm{I}, \mathrm{J}, 1)$

1270 IF $(I-1)=0$ THEN 1290

$1230 \mathrm{FE}=\mathrm{HE}+\mathrm{T}(\mathrm{I}-1, \mathrm{~J}, 2): \mathrm{III}=\mathrm{III}+\mathrm{H}(\mathrm{I}-1, \mathrm{~J}) * \mathrm{~T}(\mathrm{I}-1, \mathrm{~J}, 2)$

1290 IF $(I-N C)=0$ THEN 1310

$1300 \mathrm{EE}=\mathrm{BE}+\mathrm{T}(\mathrm{I}, \mathrm{J}, 2): \mathrm{HI}=\mathrm{III}+\mathrm{H}(\mathrm{I}+1, \mathrm{~J}) * \mathrm{~T}(\mathrm{I}, \mathrm{J}, 2)$

$1310 W=E E-A A * E(J-1): E(J)=C C / W: G(J)=(I I I-A A * G(J-1)) / W:$ NEXT J

$1320 E=E+A B S(H(I, N R)-G(N R)): H(I, N R)=G(N R): N=N R-1$

$1330 H A=G(N)-B(N) * H(I, N+1): E=E+A B S(H A-H(I, N)): H(I, N)=H A:$ $N=N-1$

1340 IF $N Y O$ THEN 1330

1350 NEXT II

1360 REM ROW CALCULATIONS

1370 FOR $J J=1$ TO NR:J $=J J:$ IF FN MOL IS + ITER $)=1$ THEN $J=N R-J+$ 1

1380 FOF $I=1$ TO NC:BE $=S F(I, J), U T A+R(I, J): U I=H O(I, J) * S F(I, J) /$ IITA $-Q(I, J)+R(1(I ; J) * R(2(I, J): A A=0.0: C C=0.0$

1390 IF $(J-1)=0$ THEN 1410

$1400 \mathrm{HE}=\mathrm{EE}+\mathrm{T}(\mathrm{I}, \mathrm{J}-1,1): \mathrm{UI}=[\mathrm{II}+\mathrm{H}(I, J-1) * \mathrm{~J}(\mathrm{I}, \mathrm{J}-1,1)$

1410 IF $(J-N R)=0$ THEN 1430

$1420 \mathrm{III}=\mathrm{III}+\mathrm{H}(I, J+1) * T(I, J, 1): \mathrm{HE}=\mathrm{EE}+\mathrm{T}(I, J, 1)$

1430 IF $(I-1)=0$ THEN 1450

$1440 \mathrm{~EB}=\mathrm{EB}+\mathrm{T}(\mathrm{I}-1, \mathrm{~J}, 2): \mathrm{AA}=-\mathrm{T}(\mathrm{I}-1, \mathrm{~J}, 2)$

1450 IF $(I-N C)=0$ THEN 1470 


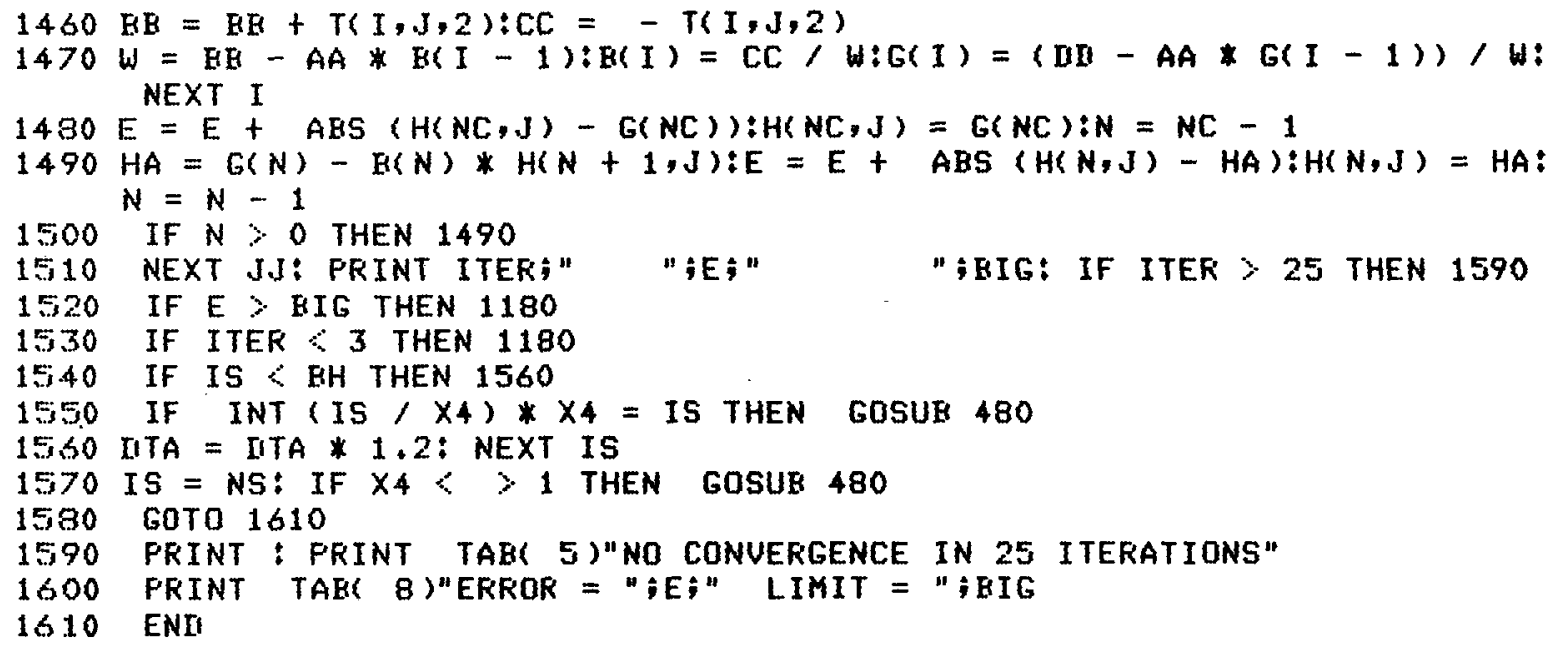

